\section{I B R I}

w w w. libridergi.org
Kitap Tanıtımı, Eleştiri ve Çeviri Dergisi

Journal of Book Notices, Reviews and Translations

SAYI IV (2018)

J. TONER, Homeros'un Türkleri: Klasik Eserler Doğu'nun Algılanmasını Nasıl Biçimlendirdi? İstanbul 2015. Tarih \& Kuram Yayınları, 240 sayfa. Çev. M. Bayatlı. ISBN: 9786059833127

\title{
Fatih ERTAŞ
}

OPEN 2

Libri: Kitap Tanıtımı, Eleştiri ve Çeviri Dergisi'nde bulunan içeriklerin tümü kullanıcılara açık, serbestçe/ücretsiz "açık erişimli" bir dergidir. Kullanıcılar, yayıncıdan ve yazar(lar)dan izin almaksızın, dergideki kitap tanıtımlarını, eleştirileri ve çevirileri tam metin olarak okuyabilir, indirebilir, dağıtabilir, çıktısını alabilir ve kaynak göstererek bağlantı verebilir.

Libri, uluslararası hakemli elektronik (online) bir dergi olup değerlendirme süreci biten kitap tanıtımları, eleştiriler ve çeviriler derginin web sitesinde (libridergi.org) yıl boyunca ilgili sayının içinde (Sayı III: OcakAralık 2018) yayımlanır. Aralık ayı sonunda ilgili yıla ait sayı tamamlanır. Dergide yayımlanan eserlerin sorumluluğu yazarlarına aittir.

Atıf Düzeni: F. Ertaş, Homeros'un Türkleri: Klasik Eserler Doğu'nun Algılanmasını Nasıl Biçimlendirdi? Yazar: J. Toner, Libri IV (2018) 69-73.

DOI: 10.20480/lbr.2018014

Geliş Tarihi: 15.01.2018 | Kabul Tarihi: 20.01.2018

Elektronik Yayın Tarihi: 25.01.2018

Editörya: Phaselis Research Project www.libridergi.org 


\section{J. TONER, Homeros'un Türkleri: Klasik Eserler Doğu'nun} Algılanmasını Nasıl Biçimlendirdi? İstanbul 2015. Tarih \& Kuram Yayınları, 240 sayfa. Çev. M. Bayatlı. ISBN: 9786059833127

\section{Fatih ERTAŞ*}

Jerry Toner'in Homeros'un Türkleri: Klasik Eserler Doğu'nun Algılanmasını Nasıl Biçimlendirdi? adlı eserinin Homer's Turk: How Classics Shaped Ideas of the East orijinal adıyla ilk kez 2013 yılında Harvard University Press tarafından Amerika'da basılmıştır. Kasım 2015'de Türkiye'de yayınlanan eser Mefkûre Bayatlı tarafından dilimize çevrilmiştir. Toner bu kitapta; İngiliz tarihçileri ile seyyahlarının Doğu'yu çoğu zaman nasıl kadim geçmiş aracılı̆̆ıyla gördükleri konusunu işliyor. İslam'ı ve Doğu'yu anlamak ve onunla ilgili algılar oluşturmak için nasıl klasik Yunan ve Roma kaynaklarına başvurduklarını araştırıyor. Aynı zamanda bu bakış açısına tarihsel, toplumsal ve politik olarak anlam kazandırarak bu koşulların "Doğulu” ötekini nasıl şekillendirdiğini ve ona karşı alınan tavırları nasıl belirlediğini açıklamaya çalışıyor. Doğu’ya ait algı ve söylem anlamında İngiliz Oryantalizminin oluşturulmasıyla ilgili birçok klasik malzemeyi bir araya getirip onları farklı tarihsel ortamlarda inceliyor. Arap, Osmanlı, Kuzey Afrika, İspanya, Hindistan ve Uzakdoğu gibi bölgelerin ve kültürlerinin Batıılar tarafından algılanması için kadim metinlerden nasıl yararlanıldığını araştırıyor.

Bu araştırma eser üç kitaptan ve on bölümden oluşuyor. Illk iki bölüm kendi içinde alt başlıklara ayrılıyor. Bunun dışında Iç̧indekiler (7-8), Önsöz (9-10) ve Dizin (233-237) kitabın diğer kısımlarını teşkil etmektedir. Kitap I Ortam

\footnotetext{
* Arş. Gör., Akdeniz Üniversitesi, Akdeniz Uygarlıkları Araştırma Enstitüsü, Akdeniz Yeni ve Yakınçağ Araştırmaları Anabilim Dalı, Antalya. fatihertas@akdeniz.edu.tr | 0 0000-0001-6905-6414
} 
(11-70) başlığının ilk bölümü, Oryantalizmlerin Klasikleştirilmesi (13-33); İngilizlerin Doğu algısı oluşturmasında klasik metinlerin önemini inceleyerek ve klasik eserlerin algılanışını ve oryantalizmi tartışır. İngiliz tarih yazımında ve seyahat yazını tarihinde algı yaratmak açısından klasiklerin oynadığı temel rollerin önemini vurgular. Bu bölümün ilk alt başlığı Klasiklerin Önemi (16-20) kısmında klasiklerin İngiliz eğitim sisteminin merkezinde yer aldığı ve İngiltere'de sınıfsal yapıyı Yunanca ve Latince bilgisinin belirlediği vurgulanır. Akabinde, Yunan ve Latin dillerinin sadece zihni geliştirdiği ve iyi vatandaşlar yaratmakla kalmadığı, aynı zamanda Roma Imparatorluğu'nun tarihinin derinlemesine incelenmesinin İngiltere'nin denizaşırı sömürgelerinin yönetilmesi için gerekli olduğu üzerinde durulur. İkinci alt başlık Klasiklerin Algılanması (20-22) kısmında klasikleri kullanmanın kadim geçmişin kalıcı değerleri çevresinde yeni ideolojiler yaratmanın bir yolu olduğu, İngilizlerin gereksinmeleri değiştikçe klasiklerin de buna uyarlandığı, İngiliz yazarların kendi gündemlerini yansıtmak için klasiklerden yararlandığı ve Doğu’yu ülkelerindeki okurlarına anlatmaya çalışırken klasiklerin çok yararlı bir kaynak oluşturduğu tartışıır. Üçüncü alt başlık Oryantalizm? (22-26) kısmında; Edward Said'in Oryantalizm anlayışını değerlendirir. Dördüncü alt başıı Seçimler (26-29) kısmında Toner bu kitabı yazmaktaki nedenlerini, projeye nasıl bir niyetle başladığını ve anlatmayı amaçladığı meseleyi açıklıyor. Ayrıca kullanılan temel kavramların kapsamları, kullanılış şekilleri ve değişkenlikleri üzerine eğiliyor. Beşinci alt başılk Bu Kitabın Yapısı (29-33) kısmında eserin yapısı, bölümleri ve kapsadığı içerikler tanıtılıyor.

İkinci üst başlık Klasikler Nasıl Kullanıldı? (35-51) bölümünde klasik göndermelerin Ingilizce metinlerde geniş kapsamlı uygulamaları ve hangi amaçlarla kullanıldıkları işlenir. Tarih ve yolculuk yazını alanında klasik göndermelerin bir sınıflandırmasını yapmak için bir kategori oluşturmaya çalışılır. Ayrıca bu göndermelerin bir araç olarak taşımak için tasarlandığı anahtar temaları ve mesajları belirler. Bu bölümün ilk alt başığı Temalar (36-41) kısmında İngiliz tarih ve yolculuk yazınında antik göndermelerin kullanımında imparatorluğun özelliği, uygarlık kavramı, bilgi edinme uğraşı ve direniş şeklinde üç tema üzerinde durulur. İngilizlerin tarihten, özellikle Roma'nın düşüşünden aldıkları ders anlatılır. İkinci alt başlık Amaçlar (41-46) kısmında farklı dönemlerde klasik metinlerin hangi amaçlar için kullanıldığına bakılır. Üçüncü alt başlık Klasikleştirmenin Mecazları ve Taktikleri (46-51) kısmında klasik göndermelerin metin içinde çok çeşitli görevler üstlendiği, gerçeklik ve 
otorite kazandırmasının yanı sıra iyi ahlak kaynağı da oluşturduğu belirtilir. Ayrıca klasik unsurların bir savı hem onaylamak hem karşı çıkmak, hem yetkilileri övmek hem de onlara meydan okumak için kullanıldığı, yazarların başka türlü güzel bir şekilde söylenemeyecek veya hiç söylenmeyecek şeyleri söylemelerine imkân tanıdığı anlatılır.

Üçüncü üst başlık Klasikler ve Ortaçağda İslam Algısı (53-70) bölümünde Ortaçağ'ın İslam algısında klasiklerin yarattığı etkiye genel bir bakış atılarak özellikle İngilizlerin Doğu hakkındaki düşüncelerinin ortaya çıkışının tarihsel arka planı incelenir. İslam'ın Roma İmparatorluğu'nun doğu bölgelerini işgal etmesi, Hıristiyan uygarlığının merkezini kuzeye, Akdeniz'in uzağına ittiği ve yeni bir Avrupa kavramının ve ideallerinin oluştuğu anlatılır.

Kitap /l Metinler (71-197) başlığı altında İngiltere tarihinin farklı dönemlerinden alınmış bir dizi İngiliz yazar incelenir. Klasiklerin nasıl kullanıldığını ve bu kullanımın nasıl geliştiği anlatılır. Çeşitli fikirlerin, mecazların ve yorumların İngiltere'nin Doğu'yla ilişkisinin tarih boyunca nasıl moda olup daha sonra gözden düştüğü üzerine durulur. Kitap // Metinler' in ilk üst başlığı Tüccarlar ve Seyyahlar (73-98) bölümünde İngiliz seyyahlarının ve tüccarlarının Osmanlı İmparatorluğu'yla çok daha yakın ilişkiler kurmaya çalıştığı 17. yüzyılda İngiltere ile İslam arasındaki ilişkiler incelenir. İkinci üst başıı Gibbon'ın İslam Tanımı (99-120) bölümünde İngiliz tarihçi Edward Gibbon'un Roma'nın düşüşü ile İslam'ın yükselişine odaklı görüşlerine yer verilir. Klasik karşılaştırmalar ve algılarla dolu anlatısı olan Gibbon, İslam'ın yükselişini, Roma'nın düşüşünün aynadaki bir yansıması gibi vererek imparatorlukların yükseliş ve düşüş nedenlerini bu bağlamda ele alır. Üçüncü üst başlık Romalı Raca (121-144) bölümünde İngiltere' nin Hindistan ile giderek artan ilişkisinin İngilizler ile Doğuluların ilişkisi konusunda yeni bir yaklaşıma nasıl acilen gerek duyulmasına neden olduğu işlenir. Hindistan ve Çin'in büyük kültürlerinin keşfi Batı́nın kendi kültürel üstünlüğü duygusunu paramparça ettiği ve barbarlara dair fikrini geçersiz kıldığı anlatılır. Dördüncü üst başlık Kadim ve Modern imparatorluklar (145-174) bölümünde Avrupalıların Doğu'ya karşı aldıkları tavırda 19. yüzyılda meydana gelen dramatik değişikliği ele alır. Ayrıca Batı ile Doğu arasındaki güç ilişkilerindeki değişim tartışılır. Klasikler vasıtasıyla Roma İmparatorluğu ile yapılan karşılaştırmalar İngilizlerin kendi sömürgecilik projelerini daha iyi anlamalarına ve karşı karşıya kaldıkları, olası tehlikeleri fark etmelerine yol açtığı anlatıır. Beşinci üst başlık Sömürge Macera- 
ları (175-197) bölümünde keşfedilmemiş son bölgelerden biri olduğu düşünülen Arabistan'a 19. yüzyılda yapılan bazı büyük seferleri inceler. 19. ve 20. yüzyılda Arabistan'a giden Charles Doughty, Richard Burton ve T. E. Lawrence gibi İngiliz seyyahları, klasik göndermeler ve örnekleri kullanarak bölgeyi ve insanlarını tanımladığı anlatılır.

Kitap III Son Sözler (200-232) başlığının ilk üst başlığı Sinema Klasikleri (201-214) bölümünde II. Dünya Savaşı'ndan sonra klasiklerin öğreniminde görülen gerilemeyle onların Doğu konusundaki algıyı şekillendirmekteki önemini yitirdiğini fakat filmlerin ve politik söylemlerin Batı́nın Doğu ile ilişkisinin canlı sahnelerini belirlemek için kadim geçmişe gönderme yapmayı sürdürdüğü anlatılır. İngiliz Hasta (1996), 300 Spartalı (1961), Sezar ve Kleopatra (1945), Kleopatra (1963), Roma (1963), Büyük İskender (1956), Carry on Cleo (1964) gibi televizyon dizisi ve filmler üzerinden Doğu algısı ve klasikler tartışılır. İkinci üst başlık Amerika Yeni Roma (215-232) bölümünde Doğu algıları ile klasik geçmişin birleşerek Amerika'nın kendi kimliğini belirlemesinde birçok bakımdan önemli bir rol oynadığına değinilir. Amerikalıların Doğu'yu ve en önemlisi kendilerini ve kendi karmaşıklıklarını anlamak için nasıl kadim dünyayı kullandığı ve klasiklerin 19. yüzyılda Amerika'nın Doğu ve Avrupalı Eski Dünya'yla bağıntılı olarak kendi kimlik duygusunu oluşturmasına yardım ettiği tartışıır. Ayrıca Vietnam Savaşı sonrasında, klasik unsurların birçok bakımdan klasik mimariyi yeniden değerlendiren ve klasik sanatın geleneksel yaklaşımdan kendini uzaklaştıran yeni bir anıtlaştırma biçiminin oluşturulmasına yardım ettiği vurgulanır. Vietnam Gazileri Anıtı gibi genelde klasik savaş anıtlarına karşıtlık oluşturan bir anıt bile Washington Anıtı'nın Mısır dikili taşını yansıtarak geçmişin devlet ideallerine yakınlık sergilediği fikri üzerinde durulur. Kadim ve modern dünyalar arasındaki benzetmeler Amerika'nın Doğu'yu ve Batı́nın onunla ilişkilerini anlaması için günümüzde de onu bilgilendirmeyi sürdürdüğü ve klasiklerin Amerikalıların Doğu'yu kendi ihtiyaçları ve endişeleri doğrultusunda şekillendirmesinde bir araç rolü oynadığı belirtilir.

Sonuç olarak; klasiklerin İngilizlerin Doğu'ya bakış açısını nasıl etkilediğine odaklanan yazar, bu kitapta kadim insanların Doğu konusundaki düşüncelerini ele almıyor. Doğu'ya dair değişmeyen algının eski çağlardan modern dünyaya çağlar boyunca nasıl geçirildiğini de izlemiyor. Doğu'nun İngiltere'de tarihsel olarak nasıl algılandığını ve klasikler yoluyla günün politik ve toplumsal gereksinmelerine göre nasıl uyarlandığını göstermeye çalışıyor. Klasiklerin 
Doğu hakkında algılar yaratmakta oynadığı önemli rolü vurguluyor. Ona göre klasikler yazarlara inceledikleri nesnelerin kırılmış görüntülerini sunan bir prizmadır. Klasikler, görüşlerin belirtilmesine yardım eder; model ve örnekler, güzel konuşma yöntemleri, görüntü, karşılaştırma, kinaye ve temsili tiplerden oluşan bir repertuvar sunar. 